\title{
GEODETIC ERRORS ARISING FROM THE DIFFERENCES BETWEEN SK-42 AND WGS-84 COORDINATE SYSTEMS WHEN IMPLEMENTED IN MODERN WEAPONS SYSTEMS
}

\author{
1̇Ilgar MUSAYEV ${ }^{(D)}$, 2 Magsad GOJAMANOV \\ ${ }^{1}$ Azercosmos Open Joint-Stock Company, Uzeyir Hajibeyli - 72, Baku, AZERBAIJAN \\ ${ }^{2}$ Baku State University, Z.Khalilov - 23, Baku, AZERBAIJAN \\ 1ilgar2533@gmail.com, 2mgodja@yandex.ru
}

(Geliş/Received: 31.09.2020; Kabul/Accepted in Revised Form: 27.12.2020)

\begin{abstract}
Modern weapons, technological systems, and facilities used in our days mainly are either managed with digital topographic maps produced in WGS-84 (World Geodetic System-1984) coordinate system or are connected with Military Geographic Information System (MGIS) created on the base of this coordinate system. If we use topographic maps based on the 1942 coordinate system in computer systems of modern weapons, and other technological systems and facilities, then it will be inevitable to encounter some geodesy related errors. In this article, these errors and their possible solutions are explained in the case of using the Krassovsky coordinate system in Azerbaijan.
\end{abstract}

Key Words: WGS-84, SK-42, MGIS, GNSS, topocentric

\section{Modern Silah Sistemlerinde Uygulandığında SK-42 ve WGS-84 Koordinat Sistemleri Arasındaki Farklılıklardan Kaynaklanan Hatalar}

ÖZ: Günümüzde kullanılan modern silahlar, teknolojik sistemler ve tesisler ağırlıklı olarak ya WGS-84 (Dünya Jeodezik Sistemi-1984) koordinat sisteminde üretilen sayısal topografik haritalarla veya temelinde şu koordinat sistemi oluşturulan Askeri Coğrafi Bilgi Sistemi esasında yönetilmektetir. Eğer modern silahların bilgisayar sistemlerinde ve diğer teknolojik sistem ve tesislerde 1942-ci yıl koordinat sistemine dayalı topografik haritaları kullanırsak, jeodezi ile ilgili bazı hatalarla karşılaşmamız kaçınılmaz olacaktır. Bu makale, Azerbaycan'da Krasovski koordinat sistemini kullanırken meydana gelebilecek hataları tartışmakta ve bunların nasıl çözüleceğini açıklamaktadır.

Anahtar Kelimeler: Dünya Jeodezik Sistemi WGS-84, Krasovski Koordinat Sistemi SK-42, Askeri Coğrafi Bilgi Sistemi, Küresel Navigasyon Uydu Sistemi, toposentrik

\section{INTRODUCTION}

In the Global Navigation Satellite System (GNSS) technique, point coordinates are expressed as geocentric $(X, Y, Z)$ or geodetic latitude, longitude, and ellipsoidal heights $(\varphi, \lambda, h)$ based on WGS-84 ellipsoid. Several errors occur when GNSS derived coordinates are used in the field together with the published topographic maps based on Krassovsky coordinate system (SK-42). These errors appear due to the following reasons:

- $\quad$ Differences in three-dimensional spatial cartesian coordinate systems;

- $\quad$ Differences between ellipsoidal and orthometric heights;

- Differences in the projections of the map systems; 
Differences in a plane rectangular coordinate systems.

\section{DIFFERENCES IN THREE-DIMENSIONAL SPATIAL CARTESIAN COORDINATE SYSTEMS}

First of all, it should be noted that when creating maps, two coordinate systems are used. One of them is a three-dimensional cartesian coordinate system, the origin of which is located in the center of the Earth. This coordinate system is called geocentric. The geocentric coordinate system determines the shape of the Earth's ellipsoid on which the map is drawn. The second coordinate system is a two-dimensional $(x, y)$ plane rectangular coordinate system. The origin of this coordinate system is taken from a point on the surface of the Earth - usually the intersection of the equator and the Greenwich meridian. A local rectangular coordinate system is called a "topocentric" coordinate system (Fig. 1), (URL1).

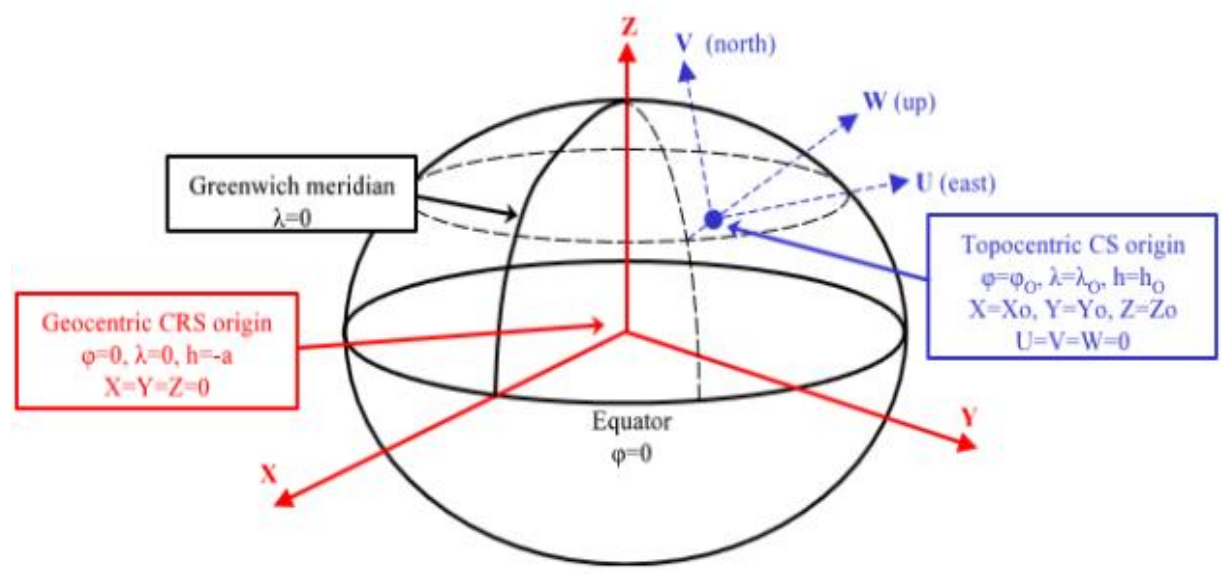

Figure 1. Geocentric and topocentric coordinate systems (URL1)

To define the rectangular topocentric coordinates of raster (electronic) topographic maps in the SK-42 coordinate system, GPS navigators must enter seven transformation parameters into the receiver's memory. These parameters are as follows:

$\Delta \mathrm{X}, \Delta \mathrm{Y}, \Delta \mathrm{Z}$ - coordinate shift;

$\omega_{\mathrm{x}}, \omega_{\mathrm{y}}, \omega_{\mathrm{z}}-$ rotation angles;

$\mathrm{m}$ - scale factor.

The transformation from the SK-42 coordinate system to the WGS-84 can be shown as follows (Musayev, 2007):

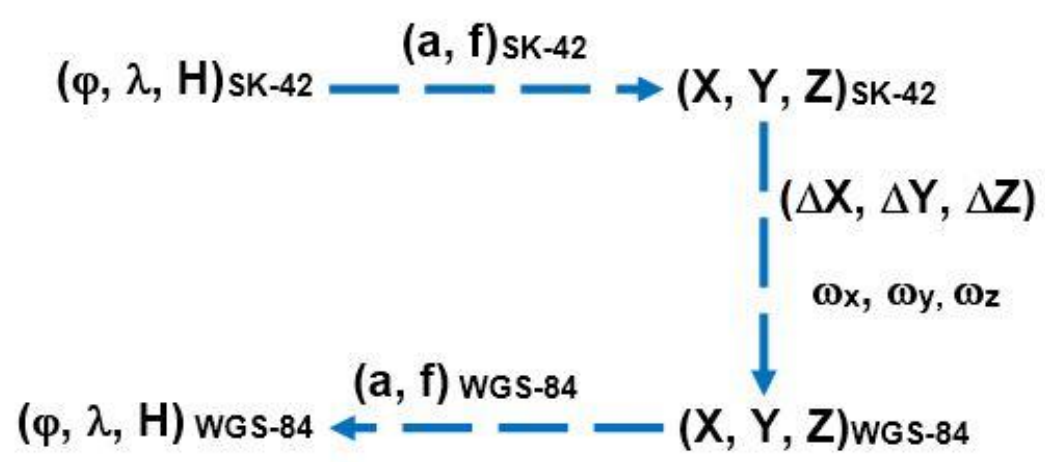

Where: 
- $\Delta \mathrm{X}=\mathrm{X}_{\text {WGS-84 }}-\mathrm{X}_{\text {SK-42, }} \Delta \mathrm{Y}=\mathrm{Y}_{\mathrm{WGS}-84}-\mathrm{Y}_{\text {SK-42, }} \Delta \mathrm{Z}=\mathrm{ZWWS}_{\mathrm{WG}-84}-\mathrm{Z}_{\text {SK-42 }}$

- $\varphi$ - geodetic latitude, $\varphi$ sK-42 $=\varphi$ wGS-84 $-\Delta \varphi$

- $\lambda$-geodetic longitude, $\lambda_{\text {sK- } 42=}=\lambda_{\text {wGS- } 84-\Delta \lambda}$

- $\quad \mathrm{a}-$ semi-major axis of the Earth ellipsoid

- $\quad b-$ semi-minor axis of the Earth ellipsoid

- $\mathrm{f}$ - flattening of the Earth ellipsoid

- $\mathrm{H}$ - orthometric height measured from mean sea level.

Here is,

$$
f=\frac{a-b}{a}
$$

For example, for the Earth's ellipsoid of the Krassovsky geodetic system $a=6378245 \mathrm{~m}$ and $b=6$ $356863 \mathrm{~m}$. The illustration of this ellipsoid is shown in Fig. 2:

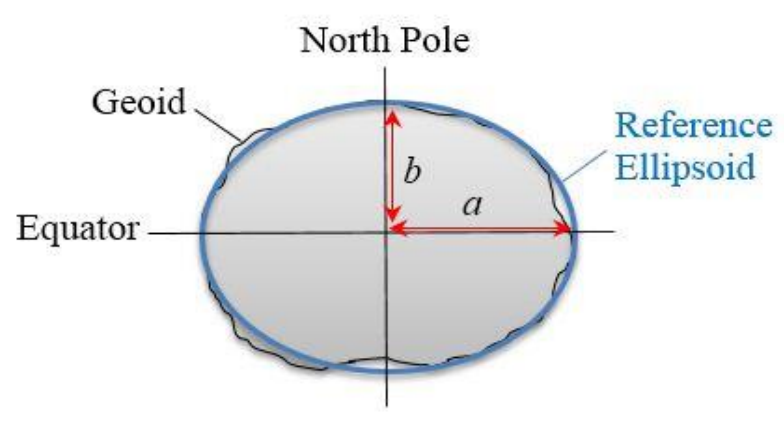

Figure 2. Earth reference ellipsoid

$$
f=\frac{a-b}{a}=\frac{21382 m}{6378245}=1: 298.3
$$

The values of transformation parameters between some coordinate systems are shown in Table 1 (Gennike and Pobedinsky, 1999):

\begin{tabular}{|c|c|c|c|c|}
\hline \multirow{2}{*}{$\begin{array}{c}\text { Transient } \\
\text { parameters }\end{array}$} & \multicolumn{4}{|c|}{ Coordinate systems } \\
\hline & $\begin{array}{l}\text { SK-42 } \\
\text { PZ-90* }\end{array}$ & $\begin{array}{l}\text { WGS-72 } \\
\text { WGS-84 }\end{array}$ & $\begin{array}{c}\text { SK-42 } \\
\text { WGS-84 }\end{array}$ & $\begin{array}{c}\text { PZ-90 } \\
\text { WGS-84 }\end{array}$ \\
\hline$\Delta X(\mathrm{~m})$ & +25 & 0 & +25 & 0 \\
\hline$\Delta \mathrm{Y}(\mathrm{m})$ & -141 & 0 & -141 & 0 \\
\hline$\Delta \mathrm{Z}(\mathrm{m})$ & -80 & $+4,5$ & $-78,5$ & $+1,5$ \\
\hline $\mathrm{m} \times 10^{-6}$ & 0 & $+0,227$ & 0 & 0 \\
\hline$\omega_{x}(')$ & $0 "$ & $0^{\prime \prime}$ & $0^{\prime \prime}$ & $0^{\prime \prime}$ \\
\hline$\omega_{\mathrm{y}}\left({ }^{\prime \prime}\right)$ & $-0,35^{\prime \prime}$ & $0 "$ & $-0,35^{\prime \prime}$ & $0^{\prime \prime}$ \\
\hline$\omega_{z}\left({ }^{\prime \prime}\right)$ & $-0,66^{\prime \prime}$ & $-0,554^{\prime \prime}$ & $-0,736^{\prime \prime}$ & $-0,076^{\prime \prime}$ \\
\hline
\end{tabular}

Table 1. Transformation parameters between different coordinate systems 
The PZ-90 (Параметры Земли 1990 года, Earth Parameters 1990) geocentric coordinate system had been proposed by geodetic scientists of the Russian Federation as a result of GLONASS / GPS measurements (Vdovin, 2012). As shown in Table-1, most parameters of the SK-42 coordinate system differ from the parameters of the WGS-84 coordinate system.

The geographic coordinates $(\varphi, \lambda)$ of the Krassovsky ellipsoid are transformed into the absolute geographic coordinates of the WGS-84 ellipsoid using seven parameters $(\Delta \mathrm{X}, \Delta \mathrm{Y}, \Delta \mathrm{Z}, \omega \mathrm{x}, \omega \mathrm{y}, \omega \mathrm{Z}, \mathrm{m})$ calculated with precise formulas. However, this is not sufficient, it is also necessary to calculate the difference between the ellipsoidal and the orthometric heights to ensure a complete transformation from the SK-42 coordinate system to the WGS-84 coordinate system.

\section{RELATION BETWEEN ELLIPSOIDAL AND ORTHOMETRIC HEIGHTS}

The ellipsoidal height (h) from the WGS-84 ellipsoid measured by GNSS receivers differs from the orthometric height $(\mathrm{H})$ measured above sea level on topographic maps of the SK-42 coordinate system (Fig. 3). Here, $\mathrm{N}$ is called geoid height which is the difference between ellipsoidal and orthometric heights.

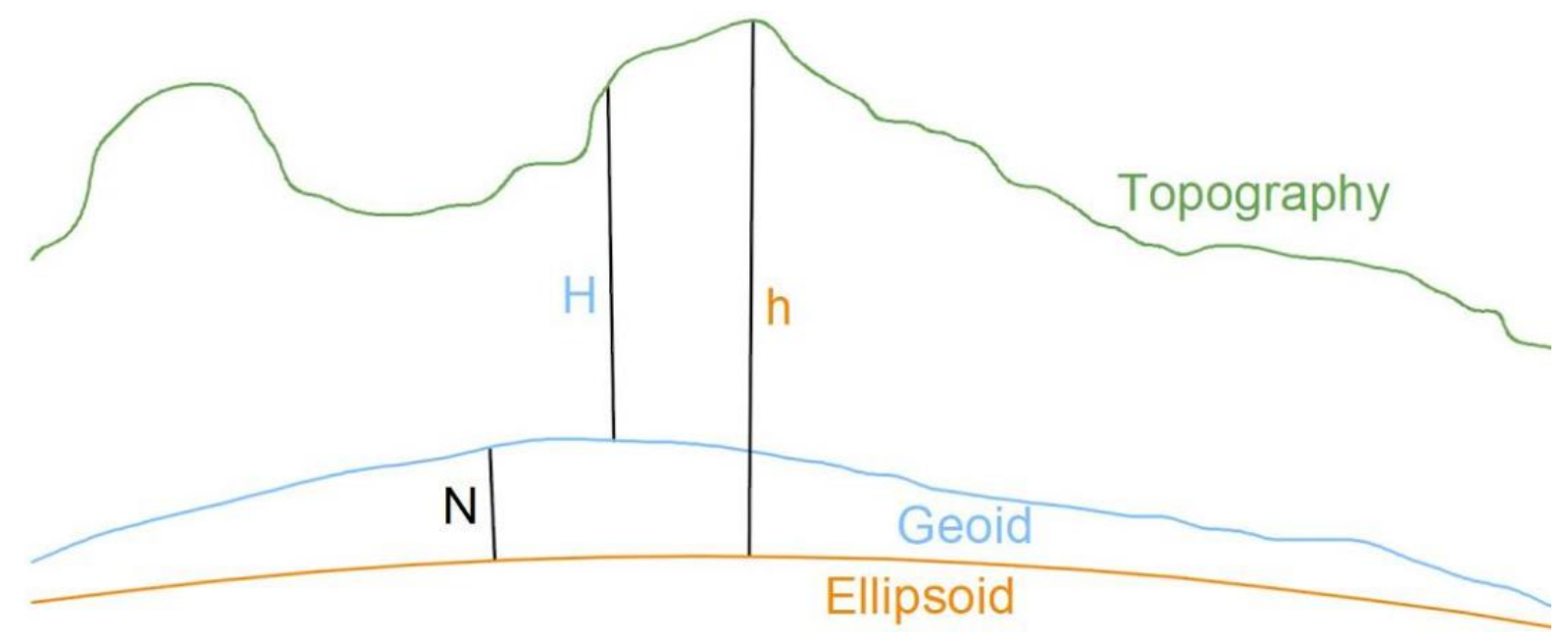

Figure 3. Relation among ellipsodal, orthometric and geoid heights (Dave, 2017)

To show this difference a field work was conducted on 15 th July 2014. Measurements were performed on class II geodetic point on Goyundag (Azerbaijan, Gobustan district) using two GNSS receivers. The ellipsoidal height measured by the 1-st receiver was - $315 \mathrm{~m}$ and the 2-nd GPS receiver was - $317 \mathrm{~m}$, while the orthometric height taken from the published coordinates of the same geodetic point was $327.6 \mathrm{~m}$. Fieldworks show that the difference between ellipsoidal and orthometric height varies between + $12.6 \mathrm{~m}$ and $+10.6 \mathrm{~m}$.

\section{DIFFERENCES IN THE PROJECTIONS OF THE MAP SYSTEMS}

Most GNSS-equipped navigation devices work on maps in the WGS-84 coordinate system and UTM (Universal Transverse Mercator) projection. Basic GIS software also works in the WGS-84 coordinate system and UTM projection maps. But the coordinate system SK-42 has been developed for maps with the Gauss-Krüger Cylindrical Conformal Projection. The UTM and Gauss-Krüger projections differ from each other in terms of the mathematical requirements of cartography. In the Gauss-Krüger projection, due to the projected $6^{0}$-zone osculating onto the cylinder, the scale everywhere remains the same, 1.000 (Musayev, 2004). In the UTM projection, the $6^{0}$-zone cylinder surface cuts along with two secant lines. Moreover, the 
scale along the central meridian of the zone is 0.9996 and 1.001 along the section of the ellipsoid (Fig. 4), (NATO STANAG 2211).

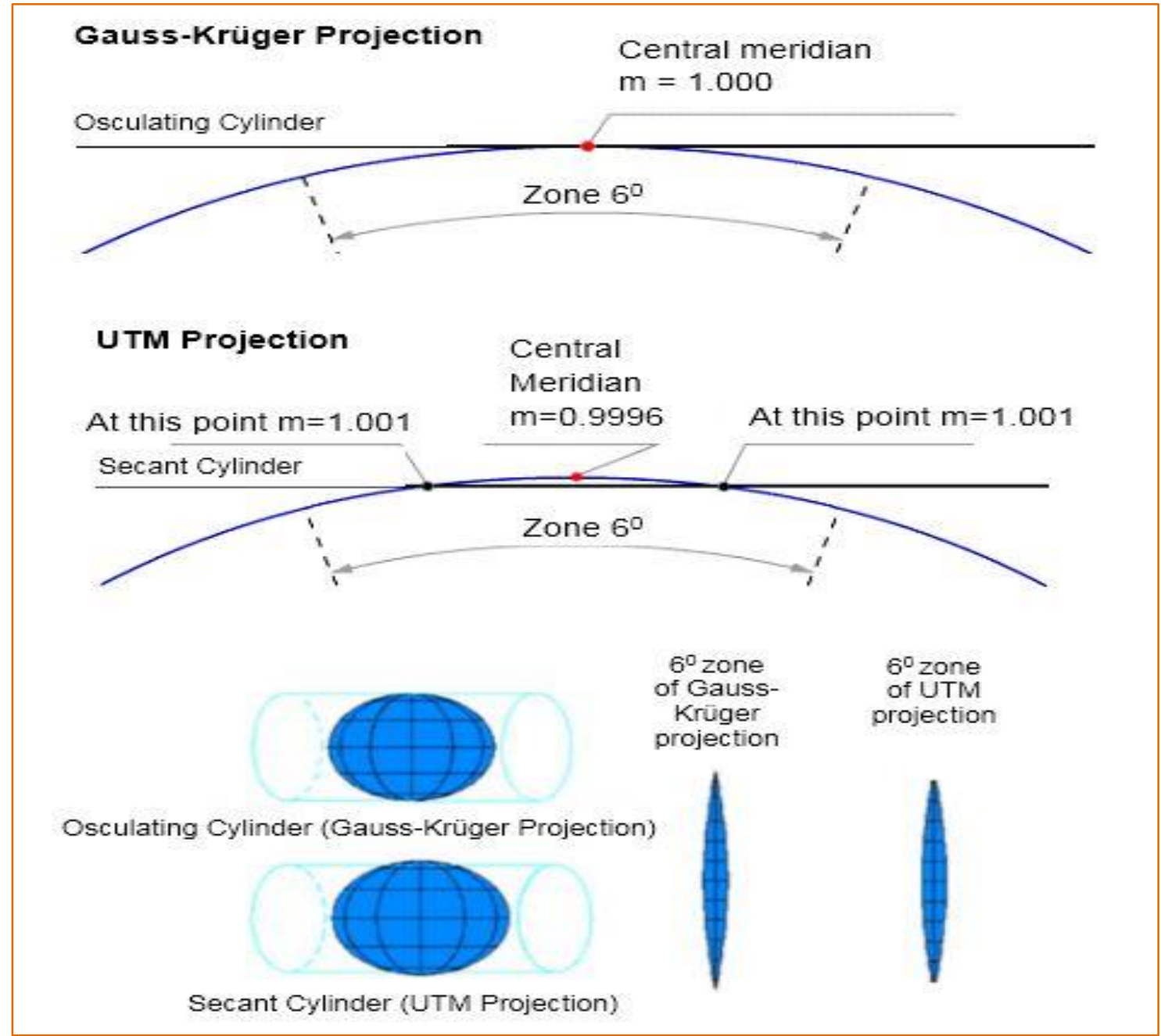

Figure 4. Differences between Gauss-Krüger and UTM projections

But there are some similarities between the Gauss-Krüger projection and the UTM projection. In both projections the Earth's surface is divided into sixty $6^{0}$ zones, starting from $180^{\circ}$ meridian. And each zone is individually projected onto the surface of the cylinder. However, due to the different projection onto the cylinder surface, the scale changes as it approaches or moves away from the middle meridian of the zone (Musayev, 2004). This accordingly affects the difference in the coordinates of the maps to which these projections apply. The difference between the coordinates increases even more towards the poles of the Earth.

\section{DIFFERENCES IN A PLANE RECTANGULAR COORDINATE SYSTEMS}

The difference in three-dimensional geographic coordinate systems between WGS-84 and SK-42 affects the difference in plane rectangular (topocentric) coordinate systems. This is because the rectangular coordinate system is based on a geographical coordinate system (Fig. 5). 


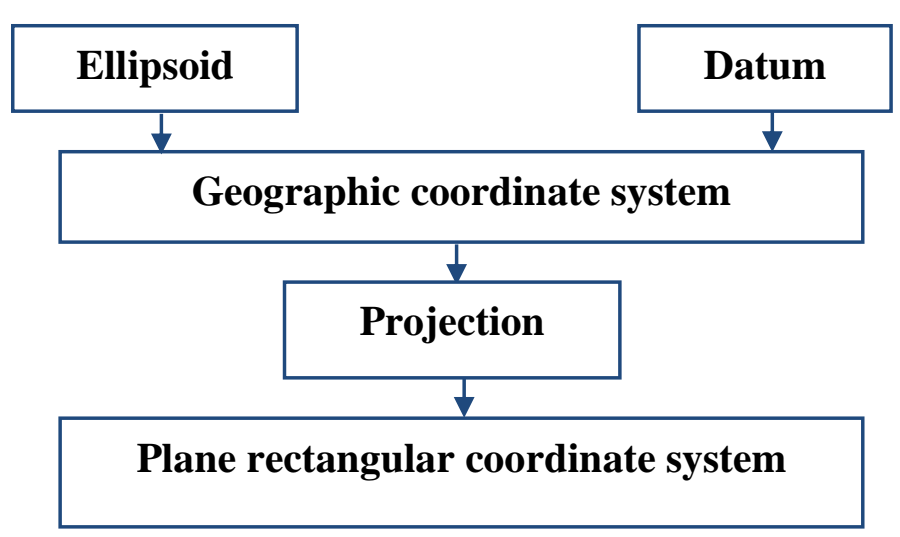

Figure 5. Transition from a geographic coordinate system to a plane rectangular coordinate system

The results of GPS measurements carried out in the field confirm the differences between the plane rectangular coordinates of SK-42 and WGS-84, (Table 2).

Table 2. Measurement results on geodetic points

\begin{tabular}{|c|c|c|c|}
\hline Geoditic points & $\begin{array}{c}\text { Coordinates taken from } \\
\text { the catalog } \\
(\mathrm{SK}-42)\end{array}$ & $\begin{array}{c}\text { GPS measurement } \\
\text { results } \\
(\mathrm{WGS}-84)\end{array}$ & Differences \\
\hline \multirow{2}{*}{$\begin{array}{l}\text { Koyundag } \\
\text { (II class) }\end{array}$} & $4483360.86 \mathrm{~m} \mathrm{~N}$ & $4481487.12 \mathrm{~m} \mathrm{~N}$ & $+1873.74 \mathrm{~m}$ \\
\hline & $374842.34 \mathrm{~m} \mathrm{E}$ & $374799.30 \mathrm{~m} \mathrm{E}$ & $+43.04 \mathrm{~m}$ \\
\hline \multirow{2}{*}{$\begin{array}{l}\text { Bozdag } \\
\text { (II class) }\end{array}$} & $4473035.69 \mathrm{~m} \mathrm{~N}$ & $4471160.73 \mathrm{~m} \mathrm{~N}$ & $+1874.96 \mathrm{~m}$ \\
\hline & $382300.22 \mathrm{~m} \mathrm{E}$ & $382257.53 \mathrm{~m} \mathrm{E}$ & $+42.69 \mathrm{~m}$ \\
\hline \multirow{2}{*}{$\begin{array}{c}\text { Bayanata } \\
\text { (II class) }\end{array}$} & $4482211.19 \mathrm{~m} \mathrm{~N}$ & $4480337.01 \mathrm{~m} \mathrm{~N}$ & $+1874.18 \mathrm{~m}$ \\
\hline & $361884.26 \mathrm{~m} \mathrm{E}$ & $361839.76 \mathrm{~m} \mathrm{E}$ & $+44.5 \mathrm{~m}$ \\
\hline \multirow{2}{*}{$\begin{array}{l}\text { Sungurdag } \\
\text { (II class) }\end{array}$} & $4484864.06 \mathrm{~m} \mathrm{~N}$ & $4482989.86 \mathrm{~m} \mathrm{~N}$ & $+1874.2 \mathrm{~m}$ \\
\hline & $352487.79 \mathrm{~m} \mathrm{E}$ & $352443.99 \mathrm{~m} \mathrm{E}$ & $+43.8 \mathrm{~m}$ \\
\hline
\end{tabular}

If we intend to connect the coordinates and ellipsoidal height data transmitted by the GPS receiver in the WGS-84 coordinate system to the maps of the SK-42 coordinate system, then we must take into account all of the above mentioned errors. When transferring geodetic and cartographic data from one coordinate system to another, it is more difficult to calculate and apply the projection and orthometric difference in the transformation parameters. While the orthometric height for topographic maps of the SK-42 coordinate system is measured from the mean level of the Baltic Sea, the orthometric height for topographic maps of the WGS-84 coordinate system is measured from the mean level of the Atlantic Ocean and the Mediterranean Sea. The problem is not only that the transformation parameters of these coordinate systems are different, but also that the maps of both coordinate systems have different standards (Table 3). 
Table 3. Comparison of topographic map parameters with the WGS and SK-42 coordinate system.

\begin{tabular}{|c|c|c|c|}
\hline No & Parameters & $\begin{array}{l}\text { Maps of the WGS-84 } \\
\text { coordinate system }\end{array}$ & $\begin{array}{l}\text { Maps of the SK-42 } \\
\text { coordinate system }\end{array}$ \\
\hline 1 & $\begin{array}{l}\text { Three-dimensional spatial } \\
\text { rectangular coordinate systems } \\
(\mathrm{X}, \mathrm{Y}, \mathrm{Z}),(\text { datum })\end{array}$ & WGS-84 & SK-42 \\
\hline 2 & $\begin{array}{l}\text { Two-dimensional plane } \\
\text { rectangular coordinate systems } \\
\text { (Topocentric coordinate system - } \\
x, y \text { ) }\end{array}$ & WGS-84 & SK-42 \\
\hline 3 & Reference ellipsoid & WGS-84 & Ellipsoid of Krassovsky \\
\hline 4 & Year of calculation & 1984 & 1940 \\
\hline 5 & Kartographic projection & $\begin{array}{l}\text { UTM (Universal Transverse } \\
\text { Merkator) }\end{array}$ & Gauss-Krüger \\
\hline 6 & Topographic symbols & $\begin{array}{l}\text { The system of symbols of } \\
\text { NATO topographic maps } \\
\text { (NATO STANAG's) }\end{array}$ & $\begin{array}{l}\text { The system of symbols } \\
\text { of Soviet topographic } \\
\text { maps }\end{array}$ \\
\hline 7 & Orthometric height & $\begin{array}{l}\text { The average sea level of the } \\
\text { Atlantic Ocean's seas and } \\
\text { the average sea level of the } \\
\text { Mediterranean Sea }\end{array}$ & $\begin{array}{l}\text { The average sea level of } \\
\text { the Baltic Sea }\end{array}$ \\
\hline 8 & $\begin{array}{l}\text { Division of maps into } \\
\text { nomenclature }\end{array}$ & $\begin{array}{l}1: 25000\left(7^{1} 30^{11} \times 7^{1} 30^{11}\right) \\
1: 50000\left(15^{1} \times 15^{1}\right) \\
1: 100000\left(30^{1} \times 30^{1}\right) \\
1: 250000\left(1^{0} 30^{1} \times 1^{1}\right)\end{array}$ & $\begin{array}{l}1: 25000\left(7^{1} 30^{11} \times 5^{1}\right) \\
1: 50000\left(15^{1} \times 10^{1}\right) \\
1: 100000\left(30^{1} \times 20^{1}\right) \\
1: 200000\left(1^{0} \times 40^{1}\right) \\
1: 500000\left(3^{0} \times 2^{0}\right)\end{array}$ \\
\hline 9 & Military Grid Reference System & + & - \\
\hline
\end{tabular}

To avoid a mismatch in the map standards, the countries of Eastern Europe, which after the collapse of the Soviet Union joined to the NATO block, abandoned the SK-42 coordinate system and began to create maps in the WGS-84 coordinate system and by the cartographic standards of this military block.

The Government of the Russian Federation, to eliminate differences between coordinate systems and ensure compliance with international coordinate systems, in 2012 adopted a Decree "On Unified State Coordinate Systems" (Decree of the Government of the Russian Federation 2012, No. 1463). The first paragraph of this resolution indicates the use of the '2011 geodetic coordinate system' (GCS-2011) for geodetic and cartographic issues and the 'Parameters of Earth 1990' geocentric coordinate system (PZ-90) for use in geodetic flight support purposes and solving navigation problems. In 2016, the government issued another Decree 'On the establishment of state coordinate systems, the state altitude system and the state gravimetric system' (Decree of the Government of the Russian Federation 2016, No. 1240). In both decrees, the use of an outdated coordinate system SK-42 is indicated for use with materials (documents) created using them.

\section{CONCLUSION}

From issues presented above, it is clear that Azerbaijan should abandon the use of SK-42 soon, and adopt internationally recognized coordinate systems and datums such as WGS84 and ITRF (International Terrestrial Reference Frame) for all practical and scientific uses in Azerbaijan. Moreover, it can also be concluded that all technological navigation and surveying systems and computer softwares should be corrected accordingly. Thus, Azerbaijan will be integrated with the modern world in terms of coordinate system and datum. 


\section{REFERENCES}

Dave Doyle, Geoid Height, https://mapitgis.com/geoid-height-extension/, 23 November 2017.

Decree of the Government of the Russian Federation "On the establishment of the state system of heights and the state gravimetric system", 28 November 2016, No. 1240, Moscow.

Decree of the Government of the Russian Federation "On Unified State Coordinate Systems”, 28 December 2012, No. 1463, Moscow.

Gennike A., Pobedinsky A., 1999, Global GPS satellite system and its application in geodesy, Cartgeocentr Geoizdat, Moscow, Russia.

Musayev I., 2004, Work on NATO topographic maps, the publishing house of the Ministry of Defense, Baku, Azerbaijan.

Musayev, I., 2007, “World Geodetic Coordinate System WGS-84”, Journal of Military Knowledge, No. 5, pp. 39-49.

NATO STANAG 2211, IGEO, “Geodetic coordinate systems and ellipsoids".

URL1: Topocentric Coordinate Reference System.

http://help.digi21.net/SistemasDeReferenciaDeCoordenadasTopocentricos.html

Vdovin, V. (2012): The role of coordinate systems in modern geodesy and mine surveying (Роль систем координат в современной геодезии и маркшейдерии) https://docplayer.ru/29192056-Rolsistem-koordinat-v-sovremennoy-geodezii-i-marksheyderii-v-c-vdovin.html, December 2012. 